\title{
Family resemblances of height, weight, and body fatness
}

\author{
L. J. HAWK AND C. G. D. BROOK
}

Department of Paediatrics, Middlesex Hospital, London

SUMMARY In a study of 256 families, among whom were twins, midparent-adult son correlations for height, weight, and combined skinfold measurements were $0.67,0.47$, and 0.23 respectively. The corresponding midparent-adult daughter correlations were $0 \cdot 63,0 \cdot 42$, and $0 \cdot 24$. Midparentgrowing offspring correlations were highest for height, less for weight, and insignificant for combined skinfold measurements. These data and the resemblances found between twins and siblings led us to conclude that there is a significant genetic contribution to the variation of height and weight, but that body fatness appears largely to be determined by environmental factors.

Twin studies have suggested body fatness in childhood to be largely genetically determined (Brook et al., 1975; Börjeson, 1976). Parent-growing offspring correlations for skinfold measurements, however, have been found to be low (Garn and Clark, 1976; Mueller and Titcomb, 1977) and to be of similar value to parent-adopted child skinfold correlations (Garn et al., 1976). As body fatness may be influenced by environmental factors - for example exercise and diet (Parizkova, 1963; Sims et al., 1968), resemblances between relatives may, more than anything else, reflect their shared common environments.

In this study, correlation coefficients of body fatness between various family members have been calculated and compared with correlations found for weight and height, the last being generally considered to be largely genetically determined (Pearson and Lee, 1903).

\section{Materials and methods}

Between 1961 and 1962, the heights and weights of parents and offspring and the skinfold measurements of offspring aged 2 to 15 were recorded for 330 families (Huntley, 1966). An attempt was made to trace these families, among whom were twins. Heights, weights, and skinfold measurements were recorded on parents and offspring. Heights were measured on a Holtain portable stadiometer,

Paediatric Department, Middlesex Hospital, London

L. J. HAWK, research fellow

C. G. D. BROOK, consultant paediatrician weights on beam scales (the subjects wearing underclothes only), and skinfolds with Holtain calipers at the triceps, biceps, subscapular, and suprailiac sites (Weiner and Lourie, 1969).

The distribution of the skinfold measurements was logarithmic. Log transformation of the data normalised the distribution (Edwards et al., 1955). Log-transformed data were used in the analysis.

The sum of the 4 skinfold measurements was used to indicate body fatness (Parizkova, 1961; Durnin and Womersley, 1974). As skinfold measurements change with age, and as the subjects were measured at widely different ages, standard deviation (SD) scores for the combined measurements of each individual were calculated. The means and SDs against which each individual was compared were the means and SDs for that individual's year group, calculated from the study population.

Weights of adult offspring were compared with the earlier weights of their parents recorded between 1961 and 1962. Heights were compared directly between adult offspring and their parents. Skinfold thickness SD scores were used to compare skinfold thicknesses between offspring and parents.

\section{Results}

$296(89 \%)$ of the families were traced and $256(78 \%)$ remeasured. The mean heights and weights of the parents and of the offspring, now aged at least 20 years, are shown in Table 1.

Parent-adult offspring correlations of height, weight, and skinfold thickness are shown in Table 2. The relationships between the anthropometric 
measurements in the parents and in their growing children varied from age to age. The yearly figures are available on request from the authors: values for parent-growing offspring correlations were highest for height, less for weight, and insignificant for skinfold thickness.

Table 1 Heights and weights (mean $\pm S D$ ) of adult offspring and their parents

\begin{tabular}{llll}
\hline & Height $(\mathrm{cm})$ & Weight $(\mathrm{kg})$ & $\begin{array}{c}\text { Mean age at time } \\
\text { of measurement }\end{array}$ \\
\hline $\begin{array}{c}\text { Fathers } \\
(\mathrm{n}=186)\end{array}$ & $172.4 \pm 0.52$ & $73.7 \pm 0.79$ & 42.2 \\
$\begin{array}{c}\text { Mothers } \\
(\mathrm{n}=211)\end{array}$ & $162.9 \pm 0.40$ & $62.3 \pm 0.53$ & 39.7 \\
$\begin{array}{c}\text { Sons } \\
(\mathrm{n}=345)\end{array}$ & $177.5 \pm 0.38$ & $69.2 \pm 0.57$ & 25.2 \\
$\begin{array}{c}\text { Daughters } \\
(\mathrm{n}=341)\end{array}$ & $164.1 \pm 0.33$ & $57.6 \pm 0.48$ & 24.9 \\
\hline
\end{tabular}

Table 2 Parent-adult offspring correlations of height, weight, and skinfold thicknesses

\begin{tabular}{|c|c|c|c|c|c|c|}
\hline & \multicolumn{2}{|c|}{ Height } & \multicolumn{2}{|c|}{ Weight } & \multicolumn{2}{|c|}{$\begin{array}{l}\text { Combined } \\
\text { skinfolds }\end{array}$} \\
\hline & $r$ & $n$ & $\boldsymbol{r}$ & $n$ & $r$ & $n$ \\
\hline $\begin{array}{l}\text { Midparent- } \\
\text { son } \\
\text { Midparent- }\end{array}$ & 0.67 & 302 & 0.47 & 302 & $0 \cdot 23$ & 238 \\
\hline $\begin{array}{l}\text { daughter } \\
\text { Father-son } \\
\text { Father- }\end{array}$ & $\begin{array}{l}0.63 \\
0.57\end{array}$ & $\begin{array}{l}287 \\
316\end{array}$ & $\begin{array}{l}0.42 \\
0.30\end{array}$ & $\begin{array}{l}257 \\
316\end{array}$ & $\begin{array}{l}0 \cdot 24 \\
0 \cdot 19\end{array}$ & $\begin{array}{l}228 \\
264\end{array}$ \\
\hline $\begin{array}{l}\text { daughter } \\
\text { Mother-son } \\
\text { Mother- }\end{array}$ & $\begin{array}{l}0.54 \\
0.59\end{array}$ & $\begin{array}{l}264 \\
332\end{array}$ & $\begin{array}{l}0 \cdot 33 \\
0 \cdot 37\end{array}$ & $\begin{array}{l}264 \\
332\end{array}$ & $\begin{array}{l}0 \cdot 10 \\
0 \cdot 21\end{array}$ & $\begin{array}{l}257 \\
311\end{array}$ \\
\hline daughter & 0.46 & 309 & 0.34 & 309 & $0 \cdot 20$ & 250 \\
\hline
\end{tabular}

Table 3 Resemblances of anthropometric measurements between twins in adult life and in childhood

\begin{tabular}{|c|c|c|c|c|}
\hline & \multicolumn{2}{|c|}{ Monozygotic twins } & \multicolumn{2}{|c|}{ Dizygotic twins } \\
\hline & Male & Female & Male/male & $\begin{array}{l}\text { Female/ } \\
\text { female }\end{array}$ \\
\hline & Adult & 20 & 46 & 45 \\
\hline Heights & 0.94 & 0.86 & 0.57 & 0.37 \\
\hline Weights & 0.85 & 0.77 & 0.43 & 0.51 \\
\hline Combined skinfolds & 0.74 & 0.81 & 0.68 & $0 \cdot 16$ \\
\hline \multicolumn{5}{|c|}{ In childhood } \\
\hline Heights & 0.95 & 0.99 & 0.95 & 0.95 \\
\hline Weights & 0.99 & 0.99 & 0.88 & 0.79 \\
\hline Combined skinfolds & 0.81 & 0.81 & 0.48 & $0 \cdot 51$ \\
\hline
\end{tabular}

Table 4 Resemblances between siblings for combined skinfold measurements

\begin{tabular}{llr}
\hline & Childhood & \multicolumn{1}{l}{ Adult } \\
\hline One in each pair a twin & & \\
Brother-brother & $0.34(68)$ & $0.36(60)$ \\
Sister-sister & $0.19(38)$ & $-0.03(48)$ \\
Neither in pair a twin & & \\
Brother-brother & $0.20(15)$ & $0.30(25)$ \\
Sister-sister & $0.34(13)$ & $0.05(20)$ \\
\hline
\end{tabular}

Analyses of the twin data in childhood and in adult life are shown in Table 3. Resemblances between siblings for combined skinfold measurements in childhood and in adult life are shown in Table 4.

\section{Discussion}

The secular trend in height is clearly shown in Table 1. The individual parent-offspring correlations (Table 2), which come close to those anticipated by Fisher (1918) for fully genetically determined characteristics, indicate that adult height is largely genetically determined. For such a characteristic, the regression coefficients of offspring on midparent $(1 \cdot 0)$ and midparent on offspring $(0 \cdot 5)$ will give a correlation coefficient of 0.71 . Our data show values which approach this and agree with previously published figures (Brook et al., 1977).

The skinfold measurements, by contrast, showed no such pattern. No resemblances were found between parents and their offspring, either as children or as adults. Sisters did not resemble one another and brothers only slightly. There is little suggestion of any genetic contribution to body fatness levels from these data.

On the other hand, correlations of skinfold thicknesses between twins in childhood taken on their own suggest a very considerable genetic contribution to the variation in skinfold measurements. The adult values were different: while monozygotic twins continued to resemble each another closely, the male dizygotic twins resembled one another more than had been the case in childhood and the female dizygotic twins showed no resemblance at all.

The parents' skinfold measurements were not taken in the first study and at the time of the second one about three-quarters of the offspring no longer lived at home. All the parent-growing offspring skinfold correlations and most of the parent-adult offspring skinfold correlations therefore reflect the fact that parents and offspring were not sharing common family environments. The lack of resemblances found in this study compared with the positive correlations found in others between parents and offspring when the offspring were still living at home (Garn and Clark, 1976; Mueller and Titcomb, 1977), suggests common family environment to be the important factor in the determination of body fatness, which the twin data do not negate.

The use of differences between monozygotic and dizygotic twins to assess the relative importance of genetic and environmental contributions to the determination of the variation of a characteristic depends upon the assumption that twins are treated more or less similarly whether they are identical or 
nonidentical. Smith (1965) noted many more similarities in environmental factors between identical twins in childhood compared with nonidentical twins. Twins who look alike were treated alike. Consequently, for a characteristic largely environmentally determined, it could be anticipated that identical twins would resemble each other more in childhood than nonidentical twins.

In collecting data from the adult twins, an attempt was made to assess activity levels. There were too many variables for satisfactory statistical analysis, but an extraordinary similarity in lifestyles and habits was noted between the identical twins. The male nonidentical twins also shared much in common and took advantage of having a brother of the same age with whom to share sporting interests. The nonidentical female twins, on the other hand, showed little in common. The resemblances in body fatness between the adult twins reflected these differences and the lack of resemblance with their singleton brothers and sisters was conspicuous.

The results for body weight lay between those for height and skinfold measurements, as would be anticipated, as weight includes both. The correlations more closely resembled the findings for height, probably because there were few obese subjects in the study group. All our analyses confirmed the widely held view that weight is conspicuously unreliable as a measure of body fatness.

Genetic factors play a large part in the determination of adult height; environmental factors largely determine adult body fatness levels. Figures derived from twin data alone should be regarded with a considerable degree of suspicion.

\section{References}

Börjeson, M. (1976). Aetiology of obesity in children. Acta paediatrica Scandinavica, 65, 279-287.

Brook, C. G. D., Huntley, R. M. C., and Slack, J. (1975). The influence of heredity and environment in the determination of skinfold thickness in children. British Medical Journal, 2, 719-721.

Brook, C. G. D., Gasser, T., Werder, E. A., Prader, A., and Vanderscheuren-Lodeweyckx, M. (1977). Height correlations between parents and mature offspring in normal subjects and in subjects with Turner's, Klinefelter's, and other syndromes. Annals of Human Biology, 4, 17-22.

Durnin, J. V. G. A., and Womersley, J. (1974). Body fat assessed from total body density and its estimation from skinfold thickness: measurements on 481 men and women aged from 16-72 years. British Journal of Nutrition, 32, 77-97.

Edwards, D. A. W., Hammond, W. M., Healy, M. J., Tanner, J. M., and Whitehouse, R. H. (1955). Design and accuracy of calipers for measuring subcutaneous tissue thickness. British Journal of Nutrition, 9, 133-146.

Fisher, R. A. (1918). The correlation between relatives on the supposition of Mendelian inheritance. Transactions of the Royal Society of Edinburgh, 52, 399-433.

Garn, S. M., Bailey, S. M., and Cole, P. E. (1976). Similarities between parents and their adopted children. American Journal of Physical Anthropology, 45, 539-543.

Garn, S. M., and Clark, D. C. (1976). Trends in fatness and the origins of obesity. Pediatrics, 57, 443-456.

Huntley, R. M. C. (1966). A study of 300 twin pairs and their families, showing resemblances in respect of a number of physical and psychological measurements. PhD thesis, University of London.

Mueller, W. H., and Titcomb, M. (1977). Genetic and environmental determinants of growth of school-aged children in a rural Colombian population. Annals of Human Biology, 4, 1-15.

Parizkova, J. (1961). Total body fat and skinfold thickness in children. Metabolism, 10, 794-807.

Parizkova, J. (1963). Impact of age, diet, and exercise on man's body composition. Annals of the New York Academy of Sciences, 110, 661-674.

Pearson, K., and Lee, A. (1903). On the laws of inheritance in man. Biometrika, 2, 357-462.

Sims, E. A. H., Goldman, R. F., Gluck, C. M., Horton, E. S., Kelleher, P. C., and Row, D. W. (1968). Experimental obesity in man. Transactions of the Association of American Physicians, 81, 153-170.

Smith, R. T. (1965). A comparison of socioenvironmental factors in monozygotic and dizygotic twins: testing an assumption. In Methods and Goals in Human Behaviour Genetics, pp. 45-61. Edited by S. G. Vandenberg. Academic Press: New York.

Weiner, J. S., and Lourie, J. A. (1969). Human Biology. A Guide to Field Methods. International Biological Programme Handbook No. 9. Blackwell: Oxford.

Correspondence to Dr C. G. D. Brook, Paediatric Department, Middlesex Hospital, Mortimer Street, London W1N 8AA.

Received 30 November 1978 